\title{
Pedagonal : Jurnal Ilmiah Pendidikan
}

http://journal.unpak.ac.id/index.php/pedagonal

\section{PENGARUH PEMAHAMAN NILAI PANCASILA TERHADAP KESADARAN ANTI BULLYING DI KALANGAN MAHASISWA PGSD}

\author{
Mira Mirawati ${ }^{\text {a) }}$, Santa $^{\text {a) }}$ \\ a) Universitas Pakuan, Bogor, Indonesia. \\ e-mail korespondensi : mira.mirawati@unpak.ac.id
}

Riwayat Artikel : diterima: 1 Maret 2021; direvisi: 16 Maret 2021; disetujui: 20 April 2021

\begin{abstract}
Abstrak. Tujuan penelitian ini untuk mengetahui pengaruh pemahaman nilai Pancasila terhadap kesadaran anti bullying di kalangan mahasiswa PGSD dengan pengambilan data kuesioner yang melibatkan 63 responden sebagai sampel penelitian. Data yang digunakan berupa data primer yang diperolah melalui penyebaran kuesioner. Teknik analisis data yang digunakan adalah analisis regresi sederhana, koefisien korelasi dan koefisien determinasi. Hasil penelitian menunjukkan terdapat pengaruh yang positif antara pemahaman nilai Pancasila terhadap kesadaran anti bullying di kalangan mahasiswa PGSD. Pengaruh tersebut dapat dilihat dari persamaan regresi $\hat{Y}=$ 71,33 - 0,05 X. Besarnya kontribusi pemahamana nilai Pancasila terhadap kesadaran anti bullying di kalangan mahasiswa PGSD ditunjukkan oleh nilai koefisien determinasi $\mathrm{r} 2$ sebesar 0,005 . Hal ini berarti peningkatan atau penurunan kesadaran anti bullying di kalangan mahasiswa PGSD dipengaruhi oleh pemahaman nilai Pancasila sebesar $0,05 \%$ sedangkan sisanya ditentukan oleh variable lain. Temuan penelitian ini menunjukkan bahwa kesadaran anti bullying di kalangan mahasiswa dapat ditingkatkan melalui pemahaman nilai Pancasila.
\end{abstract}

Kata Kunci: Pemahaman Nilai Pancasila; Kesadaran Anti Bullying; Mahasiswa PGSD

\section{THE EFFECT OF PANCASILA VALUE UNDERSTANDING ON ANTI-BULLYING AWARENESS AMONG PGSD STUDENTS}

\begin{abstract}
The aim of this study is to determine the effect of understanding the value of Pancasila on anti-bullying awareness among PGSD students by collecting questionnaire data involving 63 respondents as the research sample. The data used is in the form of primary data which is obtained through distributing questionnaires. The data analysis technique used in this research is simple regression analysis, correlation coefficient and determination coefficient. The results showed that there is a positive influence between the understandings of the value of Pancasila on anti-bullying awareness among PGSD students. This influence can be seen from the regression equation $\hat{Y}=71.33-0.05 \mathrm{X}$. The magnitude of the contribution of understanding the value of Pancasila to anti-bullying awareness among PGSD students is indicated by the coefficient of determination $\mathrm{r} 2$ of 0.005 . This means that the increase or decrease in anti-bullying awareness among PGSD students is influenced by the cultivation of the Pancasila value of $0.05 \%$, while the rest is determined by other variables. The findings of this study indicate that anti-bullying awareness among PGSD students can be increased through understanding the values of Pancasila.
\end{abstract}

Keywords: Understanding The Value of Pancasila; Anti-Bullying Awareness; PGSD Students

\section{PENDAHULUAN}

Kampus merupakan institusi pendidikan yang berfungsi untuk mendidik mahasiswa agar dapat hidup dengan sebaik-baiknya di tengah masyarakat. Melalui pendidikan dalam lingkungan kampus, mahasiswa diharapkan mampu berinteraksi dalam melakukan berbagai aktifitasnya dan berperilaku sebaik-baik sesuai dengan norma akademik yang berlaku. Norma akademik merupakan ketentuan, peraturan dan tata nilai yang harus ditaati oleh mahasiswa dalam aktivitas akademik. Tujuan norma akademik agar mengatur perilaku mahasiswa untuk tidak terjadi penyimpangan sehingga tercipta lingkungan kampus yang kondusif.

Menurut Triwahyuningsih (2015: 390), Pendidikan di lingkungan kampus yang baik akan memberikan nilai-nilai kehidupan yang berdampak pada kualitas sikap mahasiswa dalam mengembangkan nilai sosial di lingkungan masyarakatnya. Pendidikan yang menekankan pada hubungan individu yang satu dengan yang lainnya dan pentingnya penghargaan terhadap martabat manusia (human dignity) sebagai nilai tertinggi yang mendorong nilai-nilai dasar lainnya di sekitar kehidupan manusia.

Dalam beberapa kesempatan disinyalir masih terdapat penyimpangan terhadap norma akademik saat pembelajaran yakni masih rendahnya kesadaran anti bullying di kalangan mahasiswa PGSD dengan munculnya perilaku bullying. Perilaku bullying adalah tindakan kekerasan yang dilakukan oleh teman sebaya kepada seseorang yang lebih rendah atau lebih lemah untuk mendapatkan keuntungan atau kepuasan tertentu, biasanya bullying dilakukan secara berulangkali atau 
bahkan direncanakan.

Berdasarkan hasil prapenelitian yang dilakukan oleh peneliti ditemukan muncul perilaku bullying yang dilakukan oleh mahasiswa baik secara individual maupun secara berkelompok. Adapun jenis perilaku bullying yang teramati bersifat verbal langsung seperti mengejek dan mencemooh mahasiswa lainnya dengan kata-kata, dan perilaku bullying bersifat non verbal seperti mengisolasi atau mengucilkan sehingga berdampak pada korban mengalami kesulitan dalam bergaul, takut untuk berkuliah dan kesulitan berkonsentrasi dalam mengikuti perkuliahan sehingga terpengaruh pada kesehatan fisik serta mentalnya. Penyebab perilaku bullying tersebut adalah 1) konsep diri mahasiswa yang belum baik, 2) kuatnya konformitas teman sebaya, 3) mahasiswa pelaku pernah menjadi korban bullying, 4) kurangnya perhatian orang tua dan 5) rendahnya pemahaman mahasiswa tentang nilai karakter.

Perilaku bullying merupakan persoalan karakter menjadi bahan pemikiran sekaligus keprihatinan bersama dikarenakan perilaku bullying yang terjadi saat ini jauh lebih banyak jumlahnya dan kompleks. Mengingat bahaya perilaku bullying tersebut sehingga perlu adanya penanganan melalui berfungsinya pemahaman nilai Pancasila dengan baik di kalangan mahasiswa. Hal tersebut dianggap penting didasarkan pada fungsi Pancasila sebagai dasar negara Republik Indonesia memuat ideologi/ cita-cita, pandangan, dan falsafah hidup yang harus dijadikan pedoman oleh rakyat Indonesia dalam menjalankan kehidupan mulai dari ruang lingkup keluarga, masyarakat, bangsa, dan negara. Nilai Pancasila merupakan nilai-nilai baik yang ingin diwujudkan (common value) untuk terbangunnya keselarasan hidup sehingga mahasiswa berada dalam kenyamanan dan keharmonisan di lingkungan kampus dengan dimulai pemahaman nilai konsep religiusitas, humanitas, nasionalitas, loyalitas dan keadilan antarsesama. Oleh karena itu, diharapkan jika pemahaman nilai Pancasila semakin baik maka kesadaran anti bullying di kalangan mahasiswa PGSD akan meningkat.

\section{METODE PENELITIAN}

Penelitian ini dilaksanakan pada semester gasal tahun akademik 2020/2021. Sampel penelitian ini adalah mahasiswa semester IA, IB dan IC. Program Studi Pendidikan Guru Sekolah Dasar Fakultas Keguruan dan Ilmu Pendidikan Universitas Pakuan berjumlah 63 orang.

Teknik pengumpulan data yang digunakan dalam penelitian ini melalui metode angket berupa kuesioner. Instrumen kuesioner digunakan untuk mengetahui pemahaman nilai pancasila dan kesadaran anti bullying di kalangan mahasiswa. Instrumen tersebut disusun dalam bentuk pernyataan dengan menggunakan skala Likert dengan tipe pilihan yang hanya meminta responden untuk memilih salah satu jawaban dari sekian banyak jawaban (alternatif) yang sudah disediakan.

Teknik analisis data yang digunakan adalah analisis regresi sederhana, koefisien korelasi dan koefisien determinasi.

\section{HASIL DAN PEMBAHASAN}

Berdasarkan perhitungan nilai koefisien korelasi $\left(\mathrm{r}_{\mathrm{xy}}\right)$ antara pemahaman nilai Pancasila (X) dengan Kesadaran anti bullying $(\mathrm{Y})$ diperoleh nilai $\mathrm{r}=0,073$. Koefisien kausal 0,073 dikonsultasikan dengan tabel interpretasi koefisien korelasi pearson product moment $(\mathrm{r})$ : Adapun tabel interpretasi $\mathrm{r}$ adalah sebagai berikut.

Tabel 1. Interpretasi $r$

\begin{tabular}{cc}
\hline Interval Koefisien & Tingkat Hubungan \\
\hline $0,000-0,199$ & Sangat Rendah \\
$0,200-0,399$ & Rendah \\
$0,400-0,599$ & Sedang \\
$0,600-0,799$ & Kuat \\
$0,800-1,000$ & Sangat Kuat \\
\hline
\end{tabular}

Berdasarkan tabel tersebut diketahui bahwa nilai koefisien kausal $\mathrm{r}=0,074$ terdapat pada interval koefisien 0,000-0,199 yang berarti tingkat pengaruh antara dua variabel penilaian adalah sangat rendah.

Nilai koefisien determinasi $\left(\mathrm{r}^{2}\right)$ antara pemahaman nilai Pancasila $(\mathrm{X})$ dengan Kesadaran anti bullying (Y) adalah $\mathrm{r}^{2}=0,005$. Hal ini berarti bahwa pemahaman nilai Pancasila memberi konstribusi sebesar 0,05\% terhadap kesadaran anti bullying di kalangan mahasiswa PGSD.

Hal ini berarti peningkatan atau penurunan kesadaran anti bullying di kalangan mahasiswa PGSD dipengaruhi oleh penanaman nilai Pancasila sebesar $0,05 \%$ sedangkan sisanya ditentukan oleh variabel lain. Temuan penelitian ini menunjukkan bahwa kesadaran anti bullying mahasiswa PGSD dapat ditingkatkan melalui pemahaman nilai Pancasila. Andriyani (2013:16) mengemukakan kesadaran anti-bullying adalah kecenderungan seseorang untuk mencurahkan perhatiannya terhadap pengalaman yang pernah dialami untuk tidak melakukan tindakan intimidasi dengan disengaja antara pelaku dan korban yang dilakukan secara berulangulang. Lebih lanjut, syarat terciptanya kesadaran anti bullying menurut Linasari (2016:440), individu dikatakan memiliki kesadaran, bilamana individu tersebut memiliki kemampuan menghubungkan dirinya dengan lingkungannya sendiri (melalui panca indera) dan mengadakan pembatasan terhadap lingkungannya. Jika lingkungan yang sedang dihadapi individu adalah bullying, maka respon positif dari individu yang memiliki kesadaran adalah melakukan anti-bullying. Dimana, individu tersebut akan membatasi dirinya untuk tidak berperilaku bullying dan menghentikan tindakan bullying yang ada.

Kesadaran anti bullying merupakan contoh perilaku moral sebagai produk dari karakter. Jika seseorang memiliki kualitas moral intelektual dan emosional seperti baik, mereka memiliki kemungkinan melakukan tindakan yang menurut pengetahuan dan perasaan mereka adalah tindakan yang benar. Salah satu meningkatkan perilaku moral tersebut dengan cara membangkitkan kesadaran seseorang akan pentingnya memberikan komitmen terhadap nilai-nilai moral. Pendidikan moral yang tidak hanya dalam batas pengetahuan moral tetapi harus lebih pada pemahaman moral. Melinda 
(2018:13) menyatakan pemahaman moral menekankan pada alasan mengapa suatu tindakan dilakukan daripada sekedar suatu arti dari suatu tindakan itu sendiri sehingga dapat dinilai baik atau buruk. Salah satu bentuk pemahaman moral yang dapat dilakukan melalui pemahaman nilai Pancasila.

Musdalifah (2015:2) mengemukakan pemahaman nilai Pancasila merupakan pemahaman konsep Pancasila yang mengandung gagasan, cita-cita dan nilai dasar yang bulat, utuh dan mendasar mengenai eksistensi manusia dan hubungan manusia dengan lingkungannya sehingga dapat digunakan sebagai landasan dalam hidup bermasyarakat, berbangsa dan bernegara. Konsep tersebut meliputi konsep nilai religuitas, humanitas, nasionalitas, loyalitas dan keadilan.

Lebih lanjut pemahaman tersebut berkaitan dengan makna nilai-nilai Pancasila. Octavian (2019:200) mengemukakan rincian dari nilai -nilai yang terkandung dalam masing-masing sila pada Pancasila, yaitu: 1) Sila Pertama Ketuhanan Yang Maha Esa, Nilai yang terkandung pada sila ini adalah masyarakaIndonesia diharapkan memiliki rasa percaya dan takwa kepada Tuhan Yang Maha Esa sesuai dengan agama dan kepercayaan yang dianutnya, mensyukuri kehidupan yang ada, selalu menunjukkan sikap saling menghormati antar pemeluk agama lain dengan memberikan kesempatan beribadah, tidak pernah mencela keyakinan yang dianut oleh orang lain serta tidak memaksakan yang kita yakini kepada orang lain. 2) Sila Kedua Kemanusiaan Yang Adil dan Beradab. Nilai yang terkandung pada sila ini adalah setiap masyarakat Indonesia diharapkan dapat memperlakukan orang lain dan menganggap bahwa semuanya memiliki derajat, hak, dan kewajiban yang sama selaku warga negara Indonesia. sila ini juga menekankan agar memilii sikap ramah dan saling menyayangi serta gemar menjalankan kegiatan-kegiatan kemanusiaan. 3) Sila Ketiga: Persatuan Indonesia Nilai yang terkandung pada sila ini adalah setiap masyarakat Indonesia diharapkan mampu menunjukan rasa cinta tanah air atau nasionalismenya dengan cara mengedepankan rasa persatuan dan kesatuan bangsa dibandingkan dengan kepentingan individu maupun kelompoknya. Hal tersebut ditunjukkan dengan hidup rukun dengan sesama serta tidak mempermasalahkan berbagai perbedaan yang ada, 4) Sila Keempat Kerakyatan yang Dipimpin oleh Hikmat Kebijaksanaan dalam Permusyawaratan/Perwakilan: Nilai yang terkandung dalam sila ini adalah masyarakat Indonesia diharapkan mampu menunjukkan sikap yang dewasa dalam menyelesaikan suatu permasalahan, yaitu dengan cara melakukan musyawarah dan meunjukkan sikap untuk saling menghargai apendapat orang lain dalam proses pelaksanaannya serta bersifat lapang dada dan menerim setiap keputusan yang dihasilkan dari hasil musyawarah tersebutt 5) Sila Kelima; Keadilan Sosial Bagi Seluruh Rakyat Indonesia, Nilai yang terkandung pada sila ini adalah setiap masyarakat dapat menunjukkan sikap peduli terhadap sesama, lebih berempati terhadap kehidupan orang lain dengan cara berbagi kepada yang membutuhkan, tidak menunjukkan gaya hidup yang boros dan berlebihan. Selain itu, dalam mewujudkan keadilan sosial selalu berusaha memajukan diri melalui kerja keras.

\section{KESIMPULAN}

Berdasarkan hasil temuan dapat diperoleh kesimpulan bahwa terdapat pengaruh positif antara pemahaman nilai Pancasila terhadap kesadaran anti bullying di kalangan mahasiswa PGSD. Nilai konstribusi variabel pemahaman nilai Pancasila sebesar $0,05 \%$ \% sedangkan sisanya ditentukan oleh variabel lain. Peningkatan dan penurunan kesadaran anti bullying di kalangan mahasiswa dapat diprediksi melalui persamaan regresi $\hat{\mathrm{Y}}=71,33-0,05 \mathrm{X}$.

\section{REFERENSI}

Andriyani, Lusi (2013). Peningkatan Kesadaran Anti Bullying Melalui Teknik Sosiodrama pada Siswa Kelas XI SMA Muhammadiyah 1 Muntilan. Yogyakarta: Skripsi.

Linasari, (2016). Keefektifan Videotherapy dalam Menumbuhkan Kesadaran Anti Bullying pada Siswa Kelas V. Jurnal Pendidikan Guru Sekolah Dasar. 5 (36).

Melinda, Deasyari Permatan (2018). Hubungan Pemahaman Moral dengan Kecendrungan Perilaku Agresif pada Siswa-Siswi Kelas IX di SMP Negeri 50 Palembang. Jurnal Intelektualita: keislaman, Sosial dan Sains. $7(1)$

Musdalipah et.al (2015). Pengaruh Pemahaman Nilai Pancasila Terhadap Kemampuan Sosial Siswa. Jurnal System. 3(6)

Octavian, Anugerah Wendy. (2019). Upaya Peningkatan Pemahaman Nilai Pancasila terhadap siswa melalui kegiatan penyuluhan. Jurnal Bhineka Tunggal Ika, 6(2).

Pritano, Duwi (2016) Belajar Alat Analisis Data dan Cara Pengolahannya dengan SPSS. Yoyakarta: Gava Media.

Riduwan.( 2009). Belajar Mudah Penelitian untuk Guru Karyawan dan Peneliti Pemula. Bandung:Alfabeta. (n.d.). (2015) Metode \& Teknik Menyusun Proposal

Penelitian. Bandung: Alfabeta.

Sugiyono. (2002). Statistik Untuk Penelitian. Bandung: Alfabeta.

Triwahyuningsih (2015). Pelaksanaan Pendidikan Karakter di Sekolah Melalui Strategi Internalisasi Nilai Sosial. Makalah pada Prodising Revolusi Pendidikan Karakter Bangsa. Universitas Negeri Malang, Malang, Indonesia. 